\section{Non-academic staff}

SIR - I was disturbed by your swipe at the "ancillary staffs" in your comment on cuts in the budget for London University (Nature 11 June, p.442). The planned reductions in staff, in such a short space of time, show little concern for the careers and livelihoods of individuals, but are also uneconomic. The average cost to the nation of each unemployed person is estimated at $£ 5,000$ per year in lost taxes and insurance contributions and unemployment benefit paid out. This excludes the loss of purchasing power, lost VAT income and lost productivity.

You wonder whether the universities' chief purpose is academic - but the universities create, directly and indirectly, wealth. Foreign students bring money into the country - this may now be lost to Canada, the United States and New Zealand. With that go many exports, both "visible" and "invisible" (such as the "influence" which the Foreign Office has always laid great store by).

The efficiency of universities is obviously affected by lack of equipment - and also by lack of staff. Academics in general earn more than the other staffs. If non-academic staffs are reduced in preference to academics, the tasks now performed by academics will become more expensive. Their teaching and/or research time will be eaten into.

Britain spends less on pre-school education per head than any of her competitors. Since the 1972 White Paper on education, the staffstudent ratio in universities has increased by 10 per cent. During a recession one should be prepared for the recovery, otherwise recession will soon return. The cutbacks in education (and other areas) may permanently damage competitiveness.

M. HOOPER (University technician)

\section{London NI5, UK}

\section{The Tamuz raid}

SIR - I do not object to the condemnation of Israel in your issue of 18 June ("Making Israel atone for Tamuz" p.523). On the contrary, I believe that articles such as these serve a useful purpose in that they strengthen and unify the world Jewish community. Moreover, condemnations are always preferable to condolences. It is remarkable, however, that a scientific journal such as Nature should tarnish its image by publishing an unscientific report that is replete with conjecture, illconceived logic, half truths and distortions.

To the question "Why should oil-rich Iraq be interested in nuclear power?", the scientific answer given by Nature is "Why not?". A long apologetic discourse follows rationalizing the presumed logic of creating civil nuclear technology in Iraq. How foolish! The Iraqi spokesmen themselves never bothered to contrive such a rationale for their reactor. President Hussein makes no bones about it -he wants bombs. He calls upon the world to "help Arabs acquire nuclear weapons which are essential for world peace"; he also states that it is a "rational move for Arabs to try to acquire a bomb" - New York Times, 24 June, p.1.

The tears shed about the damage done to the "international reputation of the nuclear non-proliferation treaty" also amuse me. How effective are the inspections? In the case of Iraq these were conducted on a limited basis, only by representatives of Communist bloc nations. Congressional testimony by Roger Richter, former American inspector of the IAEA (19 June 1981), shows how Iraq would have easily fooled reactor inspectors. Indeed, Iraq and some other nations are signatories of the treaty, but are we talking about responsible democratic societies? How much would it take for ruthless dictators, that suppress and murder political dissidents in their own countries, to abrogate an agreement? Perhaps it is time for the current ineffectual treaty to be replaced by a more meaningful one. We should all devote our efforts to promoting effective policies that would dictate limitation to the world arms race, and stop nuclear proliferation, rather than pontificate and lecture Israel about morality.

For the sake of future generations, the scientific community has the responsibility to do everything in its power to curb the real culprits in this case; the corrupt Western powers who are prepared to place nuclear energy at the disposal of madmen. In their hearts decent people thank the heroic Israelis for undertaking this necessary mission. Nuclear power must not be handed to demented killers.

IRVING LISTOWSKY

Albert Einstein College of Medicine, New York, USA

SIR - Your editorial of 18 June (p.530) demonstrates clearly that Nature doesn't have offices in Israel. I take issue with your naive call for atonement on Israel's part for destroying Tamuz. Nations do not atone for legitimate acts of self-defence especially those committed during a declared war.

Egypt and Israel are at peace. The Egyptian nuclear programme is obviously needed for power production. For Iraq, peace with Israel is available for the asking. Nature should note that Iraq has been hostile to Israel since before Israel's independence. Iraq has not atoned for the mistreatment and expulsion of Iraqi citizens who happened to be Jewish.

It seems that you think that Israel should place its trust in the United Nations or the IAEA or the Big Powers or some other institution. Why? Did the UN stop the blockade of the straits of Tiran, did the United Kingdom and France obtain passage for Israeli shipping through the Suez Canal and when will Europe stop acquiescing in the Arab economic boycott of Israel? The credentials of world institutions do not call for trust.

Your editorial fails to mention the prospects for peace in the Middle East which were increased tremendously by the Israeli strike. It demonstrates that the cost of enmity to Israel is much higher than her enemies previously thought.

I realize that the cost to Nature of publishing a pro-Israeli editorial may be prohibitive in terms of lost advertising revenue and retaliatory terrorism but your respected journal should not dirty its image by ignoring history and simple logic to defend an attempt to destroy a nation.

State University of New York, Paul. Rothbero

Stony Brook, New York, USA

\section{No badger vaccine}

SIR - M.J. Chapman (Nature 28 May, p.278) commented on various aspects of the Zuckerman report on badgers, cattle and tuberculosis. It would be inappropriate for me to deal with the medical aspects to which $\mathrm{Mr}$ Chapman refers other than to note that my reading of these parts of the report differs from his.

I should, however, like to comment on the question of badger vaccination. The only vaccine for tuberculosis currently in use is made from a modified (attenuated) strain of Mycobacterium bovis and is used only in humans. In trials, the vaccine has given unpredictable results and is of no value at all as a treatment for infected cases. It has been tried in cattle and found to be neither effective nor practical. Its effect on badgers, whether healthy or tuberculous, is not known.

The mass vaccination of badgers seems to me, however, to be unpromising. While BCG vaccine can be given orally, yery large doses are required compared with the amount given by intradermal injection. Oral application on the scale required seems quite impracticable. Furthermore, to be effective any vaccination of badgers would in all probability have to be carried out before they had been exposed to infection. Recent work has found that 13 out of 49 young cubs removed from setts in one of the problem areas were already infected. This suggests that vaccination would need to be done soon after birth which is, unfortunately, impracticable in the wild.

$\mathrm{Mr}$ Chapman asks for consideration to be given to the views of "many zoologists" who doubt the basis of ministry policy. I can assure him that we are in contact with many zoologists, both directly and through the minister's consultative panel, and that the ministry's own zoologists are closely involved in the work.

It is not my impression that there is a body of informed zoologists who differ fundamentally with the policy that we are following. In this connection I refer Mr Chapman to the statement issued earlier this year by the Nature Conservancy Council in which they endorse Lord Zuckerman's advice.

W.H.G. REES Ministry of Agriculture, Fisheries and Food, Tolworth, UK

\section{Elementary error}

SIR - In Nature 16 April, p.538, in an article by Jasper Becker about accidents and problems at the French reprocessing plant at Cap de la Hague, mention is made of the hypothetical release of caesium-137 and rubidium-106 (if the cooling equipment for the radioactive waste storage reservoirs at $\mathrm{La}$ Hague had remained inoperative for ten hours).

Is the isotope number of rubidium perhaps in error, or the element? I do not find rubidium-106 listed in the CRC Handbook of Chemistry and Physics, 1980-81 edition.

University City, KAY DREY

Missouri, USA

The (hypothetical) of fending element is ruthenium-106 - Editor 